\section{SECTION H.}

Committee of Aid for Anthropological Excavations.-Dr. Garson called attention to the existence of a Committee of Aid formed by the Anthropological Institute for the purpose of aiding by direction or otherwise the exploration of ancient remains, the Chairman of this Committee being General PittRivers, the Inspector of Ancient Monuments. Local societies, he said, would find it to their advantage if they would report to this Committee when they were desirous of undertaking explorations.

Prehistoric Remains Committee.-Mr. J. W. Davis said that this Committee, of which he was Secretary, wanted a record of everything that had reference to prehistoric man, his dwellings, implements, pottery, \&c.

A discussion then took place with reference to the best method of imparting to the Corresponding Societies through their delegates a knowledge of what had taken place at the Conferences. Mr. Hopkinson suggested that each delegate should read a paper before his Society, giving an account of the work taken up by the various Committees, and that this paper should be published by that Society, so as to be accessible to every member of it. He distributed amongst the delegates a paper on the work of the Committees of the Association which he had brought before the Hertfordshire Natural History Society. Another question raised was the advisability of in some way bringing into relationship with the British Association certain societies which did not come up to the standard of excellence requisite for enrolment as Corresponding Societies.

On the motion of Prof. Lebour, seconded by Mr. J. W. Davis, a vote of thanks was passed to Mr. Symons, Chairman of the Conference, and to Prof. Meldola, Secretary.

\section{UNIVERSITY AND EDUCATIONAL INTELLIGENCE.}

CAMbridge.-Mr. Love, Fellow of St. John's College, has been elected Chairman of the Examiners for the Mathematical Tripos, Part I.

Prof, Darwin, Prof. J. J. Thomson, Mr. Pendlebury, St. John's, and Mr. Lachlan, Trinity, have been appointed Examiners for the second part of the Mathematical Tripos.

Mr. E. A. Parkyn, Christ's, and Mr. M. C. Potter, Peterhouse, have been appointed Lecturers in Science at affiliated lectu re-centres.

Scholarships and Exhibitions in Natural Science will be open for competition to non-members of the University in December and January next at the following Colleges: King's, Jesus, Christ's, St. John's, Trinity, Emmanuel, and Sidney Sussex (see Cambridge University Reporter, November I8, I890, p. 237).

\section{SOCIETIES AND ACADEMIES. LoNDON.}

Royal Meteorological Society, November I9.-Mr. Baldwin Latham, President, delivered an address on "The Relation of Ground Water to Disease." The pages of history show that when the ground waters of our own or other countries have arrived at a considerable degree of lowness, as evidenced by the failure of springs and the drying up of rivers, such periods have always been accompanied or followed by epidemic disease. In all probability ground water in itself, except under conditions where it is liable to pollution, has no material effect in producing or spreading disease. As a rule, it is only in those places in which there has been a considerable amount of impurity stored in the soil that diseases become manifest, and the most common modes by which diseases are, in all probability, disseminated, are by means of the water supplies drawn from the ground, or by the elimination of ground-air into the habitations of the people. It is found that the periods of low and high water mark those epochs when certain organic changes are taking place in the impurities stored in the ground, which uitimately become the cause and lead to the spread of disease. Mr. Latham defines "ground water" as all water found in the surface soil of the earth's crust, except'such as may be in combination with the materials forming the crust of the earth. It is usually derived from rainfall, by percolation; and it is also produced by con - densation. In dry countries, ground water is principally supplied by the infiltration from rivers, as, for example, in the Delta of the Nile. The absence of water passing into the ground for a long period naturally leads to the lowering of the free ground water-line, and may lead to the drying of the ground above the water-line; and it is curious to note, with reference to small-pox, that the periods marking the epochs of this disease are those in which there has been a long absence of percolation, and a consequent drying of the ground preceding such epidemics. On the other hand, small-pox is unknown at such periods as when the ground has never been allowed to dry, or is receiving moisture by condensation or capillarity. The study of underground water shows that certain diseases are more rife when the water is high in the ground, and others when the water is low. The conditions that bring about and accompany low water, however, have by far the most potential influence on health, as all low water years are, without exception, unhealthy. As a rule, the years of high water are usually healthy, except, as often happens, when high water follows immediately upon marked low water, when on the rise of the water an unhealthy period invariably follows. Mr. Latham has found that those districts which draw their water supplies direct from the ground, are usually more subject to epidemics and disease than those districts in which the water supply is drawn from rivers supplied from more extended areas, or from sources not liable to underground pollution. In the case of Croydon, one portion of the district (under threefourths) is supplied with water taken direct from the ground, whilst the remaining portion is supplied with water from the River Thames. It is curious to note that even so recently as I 885 the zymotic death-rate in the districts supplied with underground water was twice as great as in that part of the district supplied from the Thames; and in this particular year forty-one deaths from small-pox occurred in the district, not one of which was recorded outside the district supplied by the underground water. Mr. Latham, in his address, dealt largely with zymotic diseases as affected by ground water, and showed that cholera ordinarily breaks out when there is the least ground water; a high air and ground temperature is also necessary for its development, and as a rule the low-lying districts are favourable to the production of these high temperatures. Small-pox is almost always preceded by a long period of dryness of the ground, a measured by the absence of percolation. Typhoid fever is most prevalent after a dry period and the first wetting of the ground or percolation from any cause taking place. The condition essential to the development of diphtheria is a damp state of the ground marked by extreme sensitiveness to percolation of rain. Scarlet fever follows the state of the dryness of the ground, which is essential for its development, and it occurs in the percolation period. The conditions that precede small-pox are those favourable for the development of scarlet fever, and, like small-pox, the dampness of the ground for any considerable period in any particular locality, may check its development or render it less virulent, and it is most rife in low water years. Measles are least prevalent at the low water periods, and mostly rife at and near high water periods. Whooping-cough follows the percolation period in its incidence, increasing with percolation, and diminishing as the waters in the ground subside. Diarrhœa is generally more prevalent in a low water year than in other years ; that is, with a very much colder temperature in a low water year there is a very much higher death-rate from this disease. Mr. Latham finds that the general death-rate of a district is amenable to the state of the ground water, years of drought and low water being always the most unhealthy.

Geological Society, November I2.-Dr. A. Geikie, F.R.S., President in the chair. - The President referred to the sad loss the Society had sustained since the last meeting, through the death of the late Foreign Secretary, Sir Warington W. Sinyth, F.R.S. - The President reported that Mr. L. Belinfante had been temporarily appointed by the Council to the office of Assistant-Secretary.-The following communications were read :-On the porphyritic rocks of the Island of Jersey, by Prof. A. De Lapparent, Foreign Correspondent of the Society. (Communicated by the President.) The author had some years ago described as Permian a series of porphyritic rocks, of which specimens had been sent to him from Jersey. He had since been led to believe that this view of their age, arrived at frcm what he knew of similar rocks in France, was erroneous, and in a recent visit to the island had satisfied himself that the English observers who had assigned to these rocks a much higher antiquity were in the right. IIe now found that 